\title{
New and variable caddisfly species (Insecta: Trichoptera) from Bạch Mã National Park in Vietnam
}

\author{
KELLY M. MURRAY-STOKER ${ }^{1,2, *}$, JOHN C. MORSE ${ }^{3,4}$, MADELINE S. GENCO $^{5,6}$ \& HONG THAI PHAM ${ }^{7,8}$ \\ ${ }^{1}$ Department of Entomology, University of Georgia, Athens, GA, 30602, U.S.A. Currently: Department of Ecology \& Evolutionary Biol- \\ ogy, University of Toronto, Toronto, ON M5S 3B2, Canada \\ 2 |"kmmurray14@gmail.com; • ittps://orcid.org/0000-0001-7153-8092 \\ ${ }^{3}$ Department of Plant and Environmental Sciences, Clemson University, Clemson, SC 29634, U.S.A. \\ 4 ="jmorse@clemson.edu; @ https://orcid.org/0000-0003-3187-4045 \\ ${ }^{5}$ Department of Plant and Environmental Sciences, Clemson University, Clemson, SC 29634, U.S.A. Currently: Watershed Assessment \\ and Planning Branch, Office of Water Quality, Indiana Department of Environmental Management, Indianapolis, IN 46204, U.S.A. \\ ${ }^{6}$ !" maddiegenco@gmail.com; ○ https://orcid.org/0000-0002-1655-656X \\ ${ }^{7}$ Vietnam National Museum of Nature, Hanoi, Vietnam; Graduate School of Science and Technology, Vietnam Academy of Science and \\ Technology, Hanoi, Vietnam \\ 8 "” phamthai1976@yahoo.com; (1) https://orcid.org/0000-0002-4763-3679 \\ *Corresponding author: " kmmurray14@gmail.com
}

\begin{abstract}
Two new species and descriptions of variation in two previously-described species of Vietnamese Trichoptera are presented. Adult males were collected in Bạch Mã National Park, Thừa Thiên Huế Province, Vietnam. Two species in the genus Anisocentropus (Calamoceratidae) are examined here, with one new species and variations in the second species described. Two species in the family Hydroptilidae are examined, with descriptions of a new species in the genus Chrysotrichia and variation in a species of of Ugandatrichia. We provide illustrations of male genitalia for each species.
\end{abstract}

Keywords: Southeast Asia, Calamoceratidae, Hydroptilidae, species description

\section{Introduction}

Over 800 species of Trichoptera are known from Vietnam (Morse 2019). Ten species in the genus Anisocentropus McLachlan 1863 (Trichoptera: Calamoceratidae) are known from Vietnam, including five species described originally from Vietnam in subgenera Anisocentropus (hereafter Anisoc.), Anisokantropus Malicky 1994 (Anisok.), and Anisomontropus Malicky 1994 (Anisom.). These include: A. (Anisok.) cameloides Malicky 1995, A. (Anisok.) orion Mey 1997, A. (Anisom.) bungus Oláh \& Johanson 2010, A. (Anisom.) thonmihn Oláh \& Johanson 2010, and A. (Anisom.) csorbai Oláh \& Johanson 2010. Five others [A. (Anisoc.) brevipennis (Ulmer 1906), A. (Anisoc.) erichthonios Malicky \& Cheunbarn 2001 (in Malicky et al. 2001), A. (Anisoc.) kawamurai (Iwata 1927), A. (Anisom.) janus Malicky \& Chantaramongkol 1994 (in Malicky 1994), and A. (Anisom.) maculatus Ulmer 1926], were originally described from other countries, but have been documented from Vietnam as well (Arefina-Armitage \& Armitage 2015; Oláh \& Johanson 2010; Armitage et al. 2005). Here we describe a new species near A. (Anisok.) diana Malicky \& Chantaramogkol 1994 (in Malicky 1994), and we describe variation in the male genitalia for A. (Anisoc.) brevipennis, which is widespread in Southeast Asia.

The family Hydroptilidae is one of the most diverse families in the Oriental Biogeographic Region, with more than 600 species reported from the Region so far (Morse 2019). We present here a study of species from two genera: Ugandatrichia Mosely 1939 (tribe Hydroptilini Stephens 1836) and Chrysotrichia Schmid 1958 (tribe Stactobiini Botosaneanu 1956). Four of the 31 species in the genus Ugandatrichia are known to occur in Vietnam: U. frigorsi Mey 1998, U. hairanga Oláh 1989, U. honga Oláh 1989, and U. sanana Oláh 1989. Here, 
we show variation in specimens of $U$. honga. Seven of 70 species of Chrysotrichia are known from Vietnam: C. choliona Oláh 1989, C. monga Oláh 1989, C. echna Oláh \& Johanson 2010, C. hacha Oláh \& Johanson 2010, C. hailana Oláh \& Johanson 2010, C. serrula Oláh \& Johanson 2010, and C. thira Oláh \& Johanson 2010. We describe a new species near C. laoana Oláh \& Johanson 2010, which is known from Laos.

\section{Materials \& Methods}

Specimens examined here were collected from four locations in Bạch Mã National Park in central Vietnam, Thừa Thiên Huế Province, during 30 June-03 July 2017 at a range of elevations (31-1275 m a.s.1.). Sites in the park were accessed by roads or hiking trails. We collected adult caddisflies using a BioQuip (Rancho Dominguez, CA, USA) 15-watt ultraviolet light placed over a white pan filled with $95 \%$ ethanol adjacent to streams from dusk to one hour after sunset.

Abdomens of adult male specimens were cleared with $85 \%$ lactic acid over heat, following the methods of Blahnik \& Holzenthal (2004) and Blahnik et al. (2007). Pencil templates of diagnostic structures were prepared using a gridded eyepiece on a Wild ${ }^{\circledR}$ M5 dissecting microscope. Illustrations were finalized with Adobe Illustrator ${ }^{\circledR}$ CC. Specimens were preserved in 95\% ethanol and deposited in either the Vietnam National Museum of Nature (VNMN) or the Clemson University Arthropod Collection (CUAC).

\section{Family CALAMOCERATIDAE}

Anisocentropus (Anisoc.) brevipennis (Ulmer 1906)

Ganonema brevipenne Ulmer 1906: 46-47, 50, 106, fig. 56 forewing; 2 male syntypes; "Borneo"; syntypes deposited in Stettiner Museum (now Museum of the Institute of Zoology, Polish Academy of Science, Warsaw; probably lost according to Oláh \& Johanson 2010) and Paris Museum (genitalia illustrated by W. Mey 2001, personal communication to J. Oláh). Ulmer 1915: 74 (Sri Lanka). Banks 1931: 394 (Malaysian Peninsula, India).

Anisocentropus brevipennis (Ulmer 1906); Ulmer 1951: 344, 347-350, 360-363, plate 18 figs. 542-546 (male genitalia and wings).

Anisocentropus (Anisocentropus) brevipennis (Ulmer 1906); Malicky 1994: 67, plates 2 and 4 (male genitalia and wings, Thailand, Indonesia-Sumatra, Malaysia-Perak, reportedly Borneo and Sri Lanka? and India?). Malicky 2010: 330 (male genitalia and wings, Borneo, Cambodia, Peninsular Malaysia, Indonesia-Sumatra, Thailand). Oláh \& Johanson 2010: 45 (A. (A.) latifascia Diagnostic Species Group, A. (A.) brevipennis Diagnostic Species Cluster). Arefina-Armitage \& Armitage 2015: 1-19 (Vietnam).

\section{Description}

Length of each forewing 7.5-8.0 mm; in alcohol light brown with small, scattered, pale spots. Fringe of hair present on posterior margin of each hind wing.

Variation: Compared to illustrations prepared by Malicky (1994), preanal appendages shorter and more bluntly rounded apically in lateral view and more slender in dorsal view. Segment X excavated on dorsal posterior margin of our specimens (Fig 1); additionally, segment X vertically shorter in lateral view, much longer than tall. Phallus more nearly truncate distally; with more structure observed than in retracted phallus illustrated by Malicky (1994).

\section{Material examined}

Bạch Mã National Park, Thừa Thiên Huế Province, Thuy diên Waterfall, $16.2653^{\circ} \mathrm{N}, 107.8703^{\circ} \mathrm{E}$, elev. 31 m., 03 July 2017, coll. Murray-Stoker K.M., Genco M.S., Morse J.C., Nguyễn T.M., Hugnh D.H., Nguyễn V.H., 2 males preserved in $95 \%$ ethanol. Deposited in VNMN.

\section{Distribution}

Anisocentropus brevipennis was described originally from Borneo and subsequently found in Cambodia, India, Indonesia (Sumatra), Malaysia, Thailand, and Vietnam (Bunlue et al. 2012; Laudee \& Prommi 2011; Malicky 2007; Malicky et al. 2014; Nuntakwang et al. 2007; Prommi \& Chantaramongkol 2005; Seetapan \& Prommi 2012). It was previously reported from Kon Tum Province in Vietnam by Arefina-Armitage \& Armitage (2015), which is south of Thừ Thiên Huế Province, though both locations are in central Vietnam. 

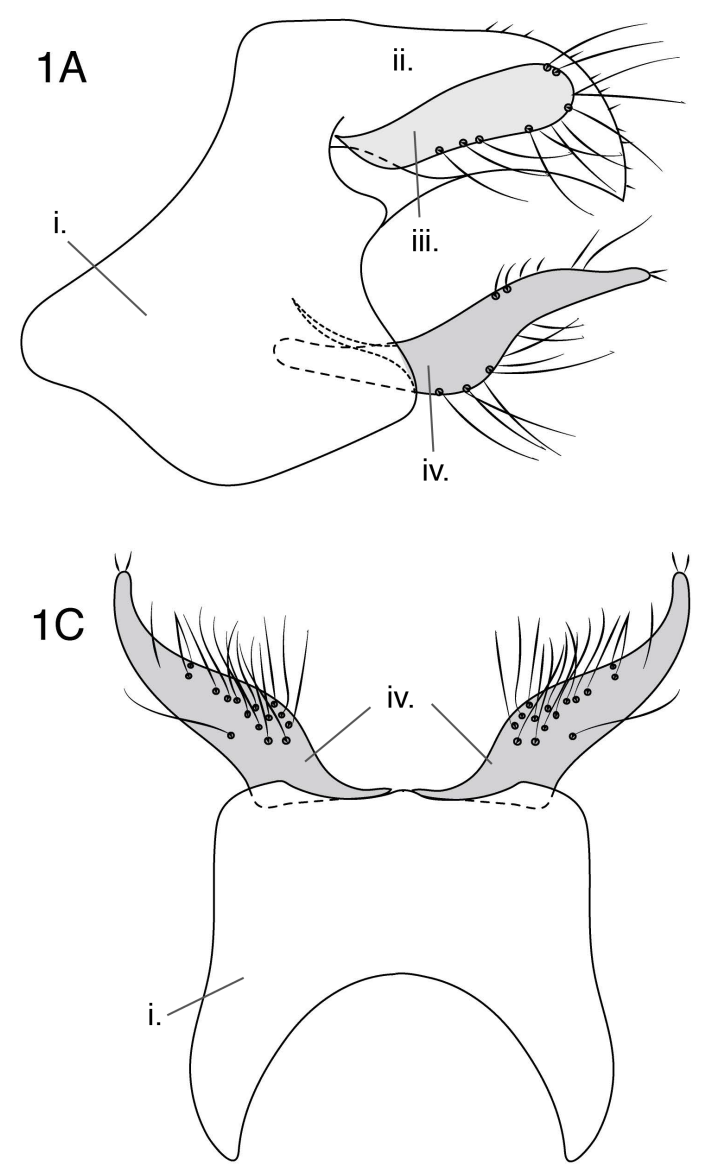

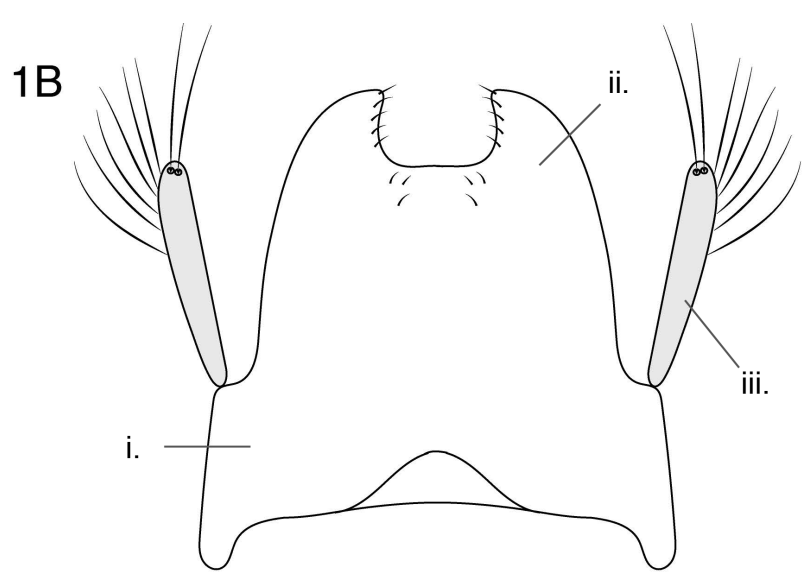

1D

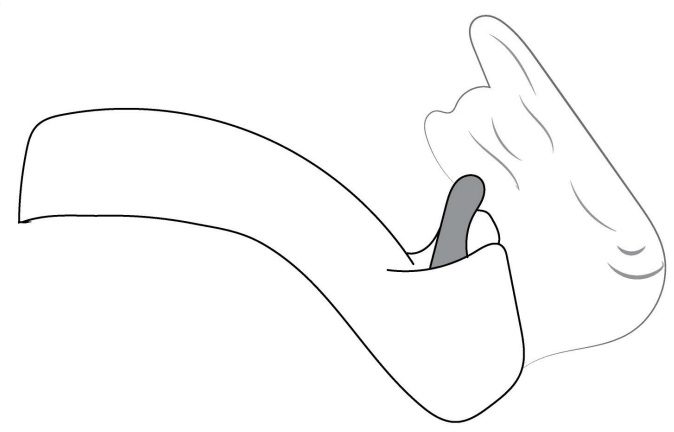

\section{$1.0 \mathrm{~mm}$}

FIGURE 1. Anisocentropus brevipennis (Ulmer 1906), variation in male genitalia of specimens from Bạch Mã National Park, Vietnam. 1A, left lateral; 1B, dorsal; 1C, ventral; 1D, phallus, left lateral. Lables: i. segment IX; ii. segment X; iii. preanal appendage; iv. inferior appendage.

\section{Anisocentropus (Anisok.) minerva Murray-Stoker \& Morse, new species}

\section{Description}

Length of each forewing $8.0 \mathrm{~mm}$; in alcohol brown, with small, scattered, pale spots. Fringe of hair present on posterior margin of each hind wing, with hair on basal portion being longest. Body yellow-brown and mesoscutal setal area darker brown.

Male Genitalia (Fig. 2): Dorsum IX with acute anteromesal notch and with pair of raised setose lobes near posterior margin; pair of posterior dorsolateral lobes not extending past lateral margins of segment. Preanal appendages in lateral view oval with median constriction; subtriangular in dorsal view with broadly rounded mesal angles, scalloped posterior margins, and blunt apices. Segment X divided mesally to base; in lateral view with paired and acutely pointed dorsal and ventral angles and no subdorsal angles, each dorsal angle setose, each ventral angle forming smooth downward curve; in dorsal view each half of tergum X triangular and apically tapered, with outer margin ridged and bearing short setae, inner margin with short mesal point. Inferior appendages in lateral view each with setose basoventral lobe and setose subbasodorsal lobe, slender distal portion as long as basal portion; in ventral view gradually curved mesad, distal portion apically straight and obliquely truncate. Phallus in lateral view downcurved in basal half, conspicuously curved upward in distal half; single ventromesal ridge at midlength; larger pair of subapicodorsal ridges forming mesal depression. 


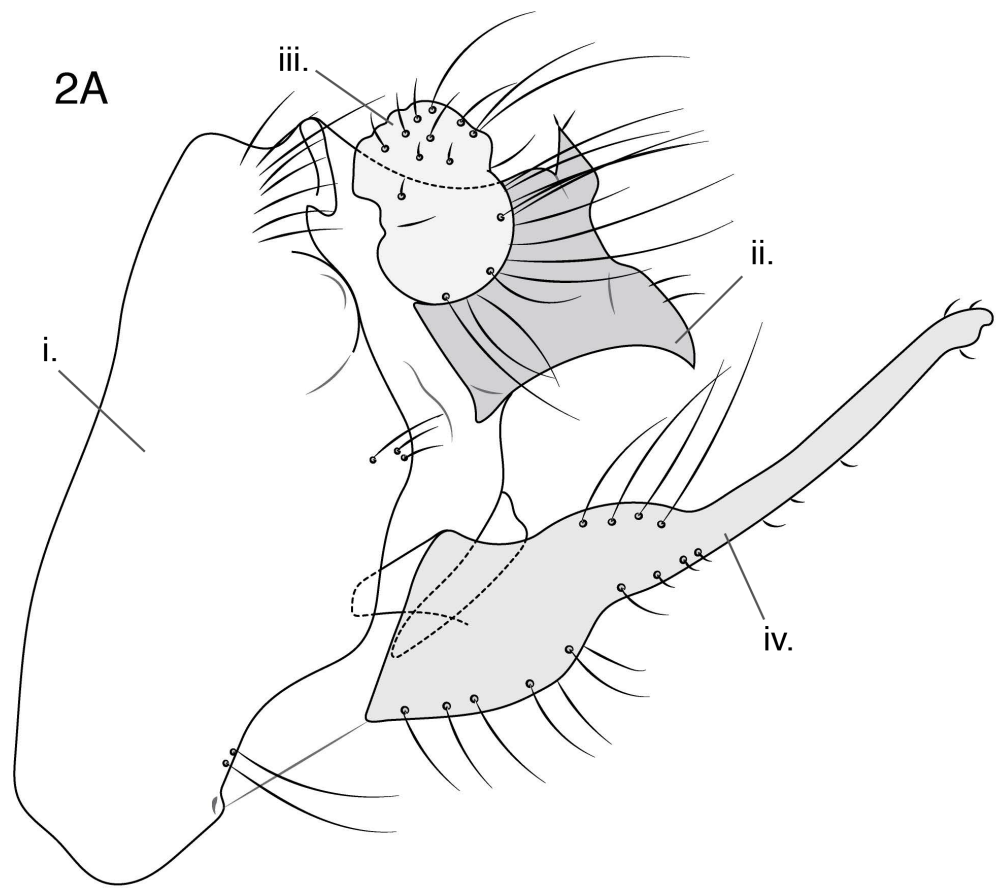

2B
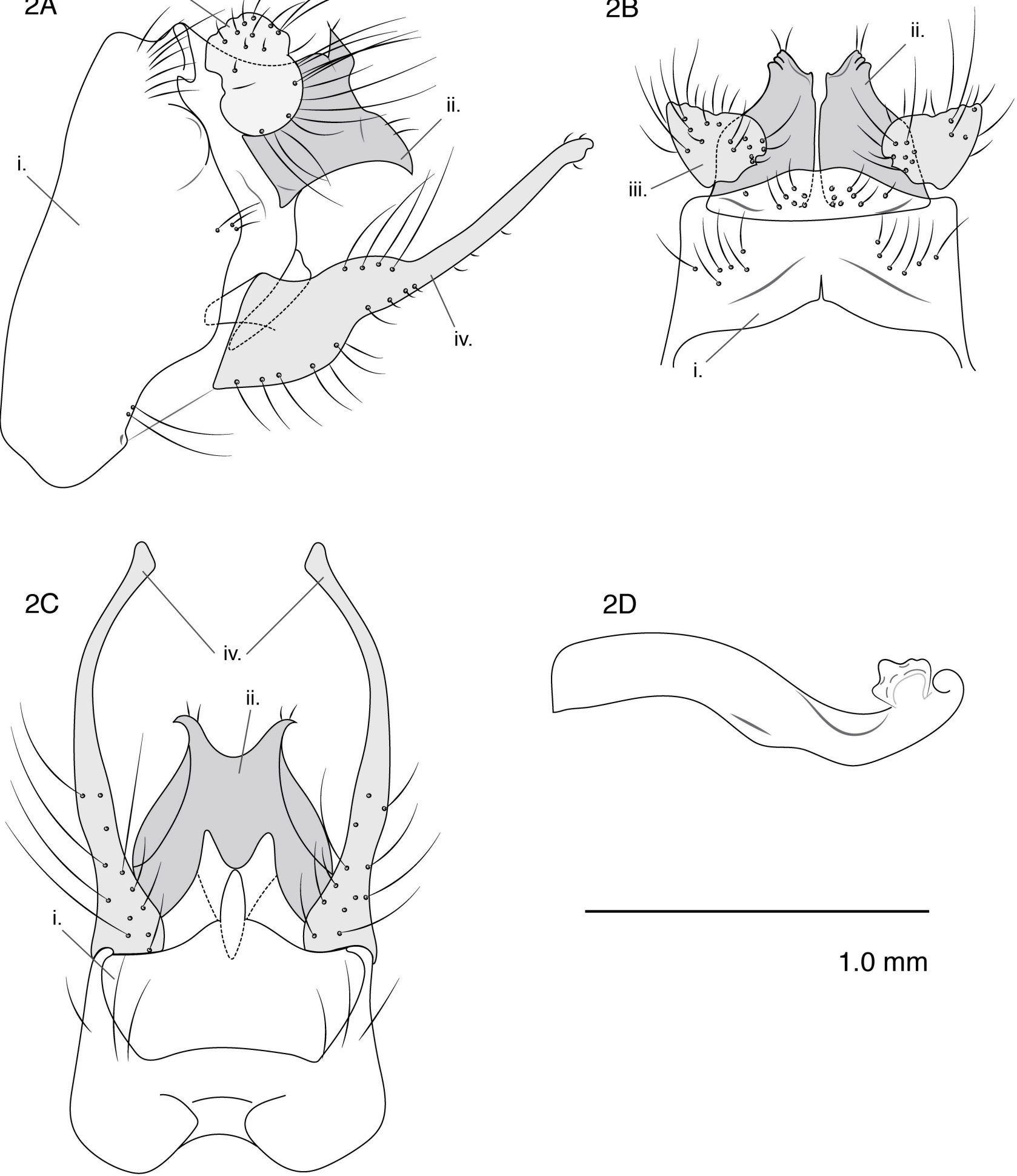

FIGURE 2. Anisocentropus minerva Murray-Stoker \& Morse, new species, male genitalia. 2A, left lateral; 2B, dorsal; 2C, ventral; 2D, phallus, left lateral. Lables: i. segment IX; ii. segment X; iii. preanal appendage; iv. inferior appendage.

\section{Diagnosis}

This species is most similar to A. (Anisok.) diana Malicky \& Chantaramongkol 1994 (in Malicky 1994), known from Thailand, Malaysia, and Indonesia (Sumatra) (Bunlue et al. 2012; Malicky 1994, 2007, 2010; Nuntakwang et al. 2007; Oláh \& Johanson 2010). The new species differs in the following ways: The poste- 
rior dorsolateral lobe on each side of segment IX is not as pronounced as in A. diana. The preanal appendages have distal margins convex mesally scalloped distally and blunt apically in dorsal view, rather than angled and straight and acute as in $A$. diana. Segment $\mathrm{X}$ is divided mesally to its base and the distal portion of each division is more tapered and differently shaped than the examples of variation noted by Malicky \& Chantaramongkol (in Malicky 1994; Malicky 2010). The distal portion of each inferior appendage is relatively longer (as long as basal portion) and in ventral view straight and obliquely truncate apically in A. minerva $\mathrm{n}$. sp.; the distal portion is much shorter than the basal portion and the apices are curved mesad and blunt apically in $A$. diana. The phallus is more sinuous in lateral view and distinctly upcurved distally and has ventromesal and subapicodorsal ridges in $A$. minerva $\mathrm{n}$. sp. but is nearly straight and without ridges in $A$. diana.

\section{Etymology}

Named for the maiden goddess of wisdom in Roman mythology, because it is similar to A. diana, named for the Roman goddess Diana, maiden goddess of the hunt, the moon, and nature.

\section{Material examined}

Holotype male: Bạch Mã National Park, Thừa Thiên Huế Province, where two tributaries meet 5-Lakes Stream, upstream of 7-m-deep pool, $16.1922^{\circ} \mathrm{N}, 107.8559^{\circ} \mathrm{E}$, elev. 1275 m., 03 July 2017, coll. Murray-Stoker K.M., Genco M.S., Morse J.C., Nguyễn T.M., Hugnh D.H., Nguyễn V.H., preserved in 95\% ethanol; deposited in VNMN.

\section{Family HYDROPTILIDAE}

Ugandatrichia honga Oláh 1989

Ugandatrichia honga Oláh 1989: 275-276, figs. 20A-20C; male; Vietnam; deposited in the Hungarian Natural History Museum, Budapest. Yang et al. 2005: 441-460 (China). Laudee 2008: 29-39 (larva, Thailand). Malicky 2010: 35 (male genitalia, Thailand and Vietnam). Oláh \& Johanson 2010: 100 (Laos).

Ugandatrichia navicularis Xue \& Yang 1990: 125-126, 130-131, figs. 2A-2C; male; China (Hainan); deposited in the Insect Collection of Nanjing Agricultural University, Nanjing, PR China. Synonymized by Malicky 2013: 43.

\section{Description}

Length of each forewing $2.5 \mathrm{~mm}$; short, thick hair present and concentrated on anterior forewing margin. Wings and body in alcohol uniformly medium brown.

Variation (Fig. 3): Segment IX posterior dorsolateral and lateral margins more strongly projecting than in any of the previously described specimens of this species. Inferior appendages of types and our specimen longer and more slender in lateral view than those of specimen illustrated by Malicky (2010), those of our specimens each without acute subapicodorsal point of types. Phallus apically truncate, unlike that of any of the previously described specimens.

\section{Material examined}

Bạch Mã National Park, Thừa Thiên Huế Province, tributary to Pheasant Falls (tributary to Truoi River), $16.2287^{\circ} \mathrm{N}, 107.8486^{\circ} \mathrm{E}$, elev. 159 m., 30 June 2017, coll. Murray-Stoker K.M., Genco M.S., Morse J.C., Nguyễn T.M., Hugnh D.H., Nguyễn V.H., 1 male preserved in 95\% ethanol. Deposited in VNMN.

\section{Distribution}

This species was described originally from northwestern Vietnam by Oláh (1989) and is also known from Thailand, China, and Laos (Bunlue et al. 2012; Laudee 2008; Laudee \& Prommi 2011; Oláh \& Johanson 2010; Yang et al. 2016). Our record from central Vietnam extends the range southward in this country. 

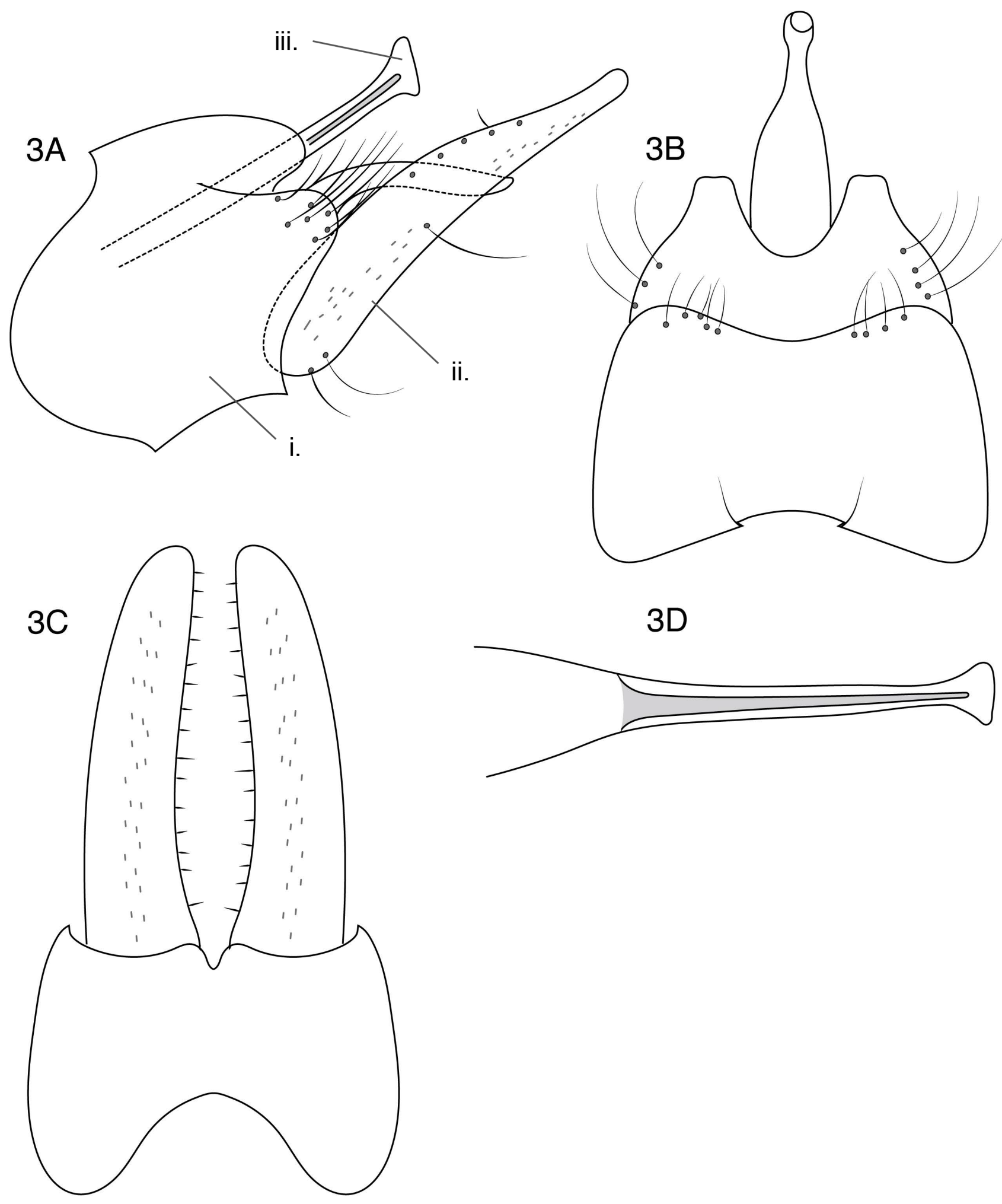

\section{$0.5 \mathrm{~mm}$}

FIGURE 3. Ugandatrichia honga Oláh 1989, variation in male genitalia of specimens from Bạch Mã National Park, Vietnam. 3A, left lateral; 3B, dorsal; 3C, ventral; 3D, phallus, left lateral. Lables: i. segment IX; ii. inferior appendage; iii. phallus. 

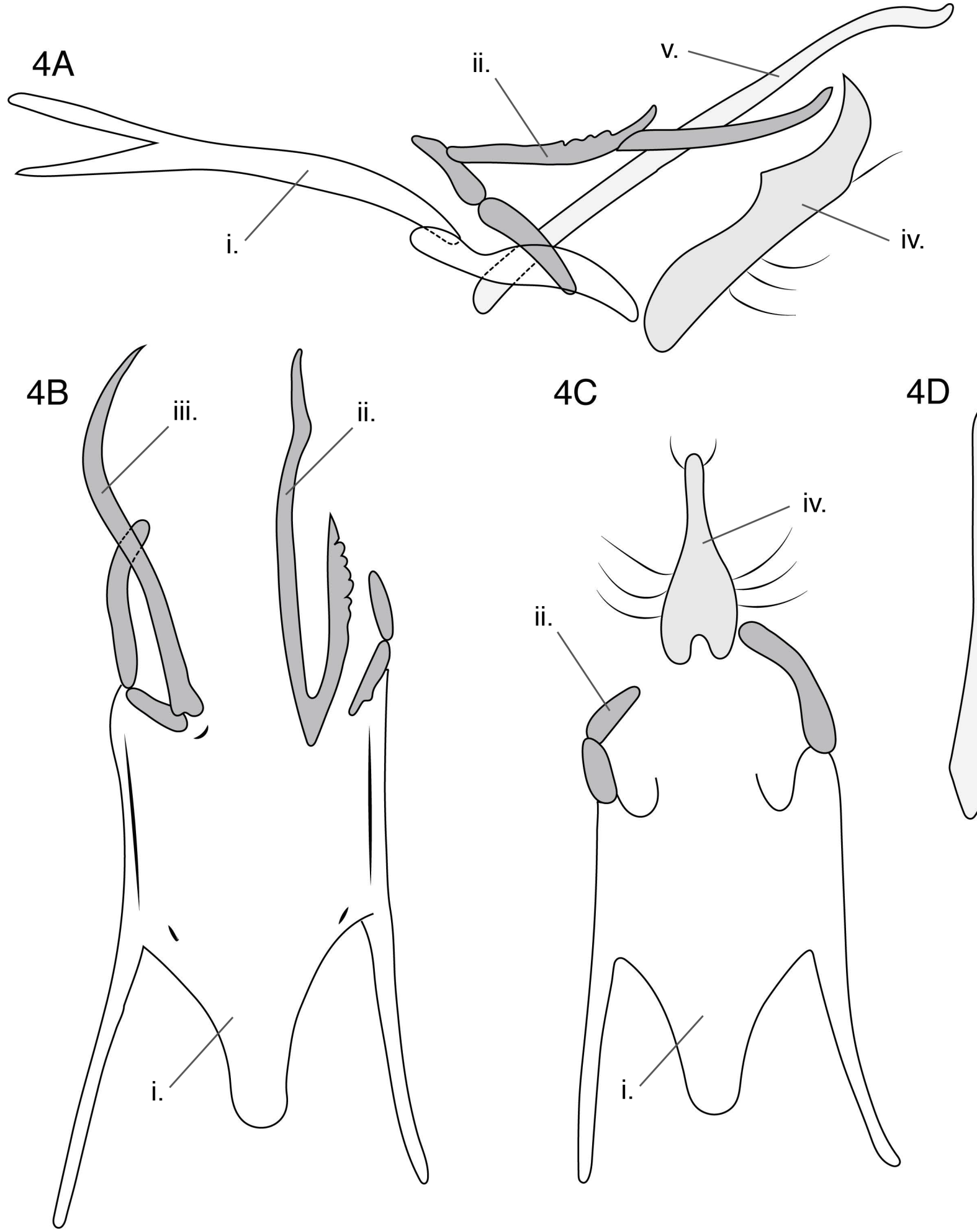

4C
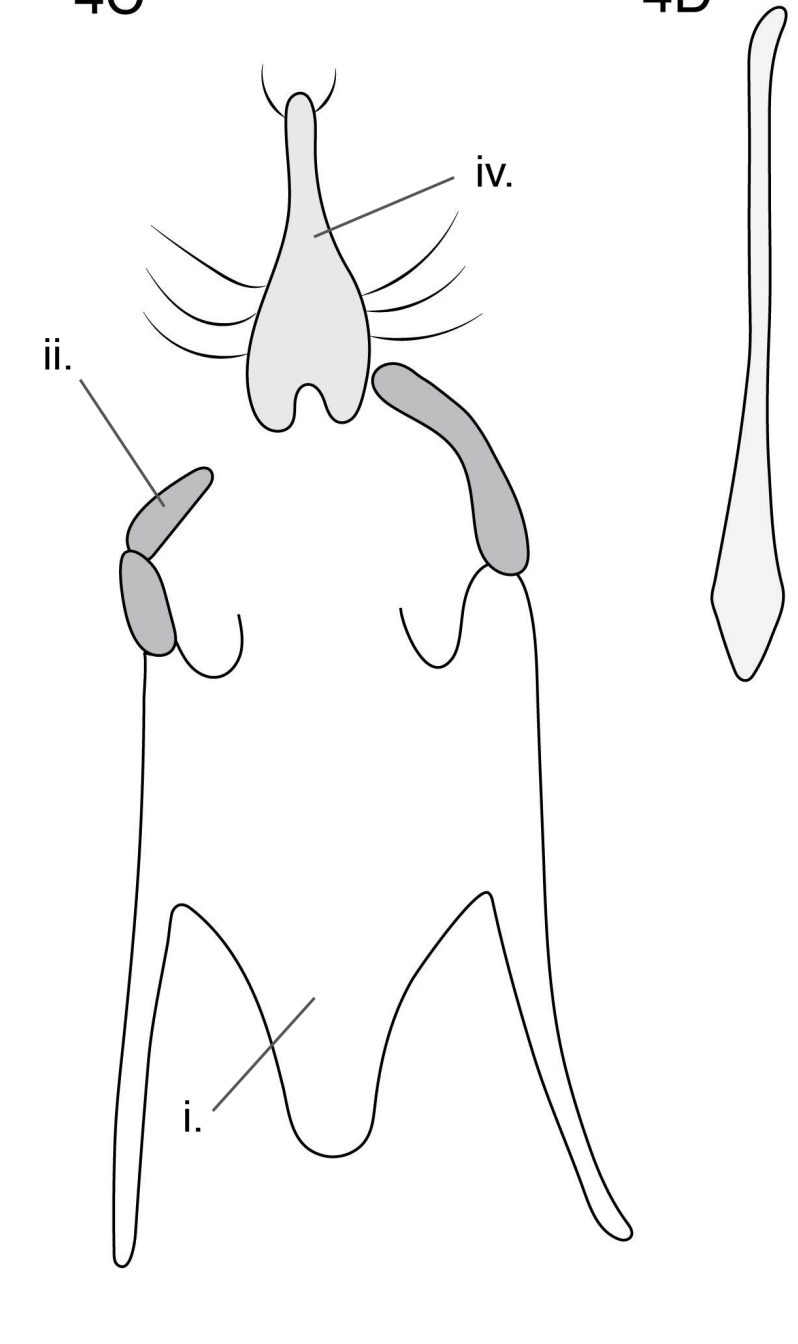


\section{Chrysotrichia bachma Murray-Stoker \& Morse, new species}

\section{Description}

Length of each forewing $1.0 \mathrm{~mm}$; with hair on distal half of anterior and posterior margins. In alcohol body and wings uniformly gray-brown.

Male genitalia (Fig. 4): Segment IX with three anterior apodemes; median apodeme with rounded anterior margin and not as long as lateral apodemes. Paraprocts each 3-segmented; long arm of right paraproct curved outward and then mesad from midline; long arm of left paraproct with only slight subapical curve and left paraproct with with basal process having a serrated outer margin. Fused inferior appendages in ventral view rounded in basal $2 / 3$ and with anterior incision and nearly parallel-sided in distal $1 / 3$; in lateral view, inferior appendages each with dorsal tooth beyond midlength and curved upward to apical point, with setae on ventral margin. Phallus parallel-sided tube for most of its length, expanded basally and slightly curved to left distally.

\section{Diagnosis}

This species appears most similar to C. laoana Oláh \& Johanson 2010, which was described close to C. thira Oláh \& Johanson 2010. These species also resemble C. barisan Oláh \& Johanson 2010, C. ganjil Wells \& Huisman 1993, C. quirinus Malicky \& Chantaramongkol 2007, C. serrula Oláh \& Johanson 2010, C. skamandros Malicky \& Chantaramongkol 2007, C. thira Oláh \& Johanson 2010, and C. zoroastres Malicky \& Chantaramongkol 2007 by having a depressed (dorsoventrally flattened) segment IX with a long anteromesal lobe, spine-like paraprocts ("dorsal rods" auctt.), and fused and tapering inferior appendages. Among all of these species, only C. laoana and this new species have a separate serrate basal process on the left paraproct.

Compared to C. laoana, segment IX of the new species is much more depressed. The median apodeme of segment IX is rounded in C. bachma n. sp. rather than truncate. The paraprocts each appear 3-segmented in $C$. bachma n. sp., rather than 2-segmented as in C. laoana, and strongly asymmetrical (nearly symmetrical in $C$. laoana). The fused inferior appendages in C. bachma $\mathrm{n}$. sp. have a dorsal tooth beyond midlength; this projection arises before midlength in C. laoana.

\section{Etymology}

Named for Bạch Mã National Park in Vietnam, where the specimens were collected.

\section{Material examined}

Holotype male: Bạch Mã National Park, Thừa Thiên Huế Province, tributary to Pheasant Falls (tributary to Truoi River), $16.2287^{\circ}$ N, $107.8486^{\circ}$ E, elev. 159 m., 30 June 2017, coll. Murray-Stoker K.M., Genco M.S., Morse J.C., Nguyễn T.M., Hugnh D.H., Nguyễn V.H.; deposited in VNMN. Paratypes: 5 males preserved in $95 \%$ ethanol ( 2 males in VNMN, 3 males in CUAC).

\section{Discussion}

Scientific understanding of Southeast Asia's diverse caddisfly fauna is growing (Malicky 2010), and there is likely still more diversity to be discovered (Morse 2016). Descriptions of new and previously described species are presented here in order to contribute to knowledge of Vietnamese Trichoptera species diversity and distribution in this country and region.

The current effort to establish a library of DNA barcodes will help to determine further whether variation, such as that described here, actually corresponds to separate species, and possibly make progress toward deeper understanding of Trichoptera phylogeny (e.g., Zhou et al. 2016).

Establishing a library for of DNA sequences Trichoptera of the Oriental Biogeographic Region will also aid in the association of larvae with described adults; currently, less than $1 \%$ of species in this region have larval associations and descriptions (Morse 2016). The ability to identify larvae to species may help illuminate ecological correspondences of the species, including those described here. 


\section{Acknowledgements}

We are grateful to T.M. Nguyễn, V.S. Mai, T.H.Y. Tô, V.H. Nguyễn, and D.H Hugnh for their help with fieldwork and collections. We also thank H. Malicky for his assistance regarding the identification of these specimens.

\section{References}

Arefina-Armitage, T. \& Armitage, B. (2015) New species and new country records for Vietnamese caddisflies (Insecta: Trichoptera). Insecta Mundi, 438, 1-19.

Armitage, B., Mey, W., Arefina, T. \& Schefter, P. (2005) The caddisfly fauna (Insecta: Trichoptera) of Vietnam, In: Tanida, K. $\&$ Rossiter, A. (Eds.), Proceedings of the 11th International Symposium on Trichoptera. Tokai University Press, Kanagawa, pp. $25-37$.

Banks, N. (1931) XVIII.- Some neuropteroid insects from the Malay Peninsula. Journal of the Federated Malay States Museums, 16, 377-409.

Blahnick, R.J. \& Holzenthal, R.W. (2004) Collection and curation of Trichoptera with an emphasis on pinned material. Nectopsyche: Neotropical Trichoptera Newsletter, 1, 8-20.

Blahnik, R.J., Holzenthal R.W. \& Prather, A. (2007) The lactic acid method for clearing Trichoptera genitalia. Proceedings of the XIIth International Symposium on Trichoptera, 9-14.

Botosaneanu, L. (1956) Recherches sur les Trichoptères de Bulgarie recueillis par MM. le Prof. A. Balkanov et B. Rusev (Trichoptera). Beiträge zur Entomologie, 6, 354-402.

Bunlue, P., Chantaramongkul, P., Thapanya, D. \& Malicky, H. (2012) The biodiversity of Trichoptera assemblage in Doi Suthep-Pui and Doi Inthanon National Parks, Chiang Mai, Thailand. Braueria, 39, 7-21.

Iwata, M. (1927) Trichopterous larvae from Japan. Dobutsugaku Zasshi, 39, 209-272.

Laudee, P. (2008) Larval morphology and diagnosis of the giant microcaddisfly species, Ugandatrichia spp. (Hydroptilidae: Trichoptera) in Thailand. Zootaxa, 1825, 29-39.

https://doi.org/10.11646/zootaxa.1825.1.3

Laudee, P. \& Prommi, T-o. (2011) Biodiversity and distribution of Trichoptera species along the Tapee River, Surat Thani Province, southern Thailand. Zoosymposia, 5, 279-287. https://doi.org/10.11646/zoosymposia.5.1.21

Malicky, H. (1994) Ein Beiträg zur Kenntnis asiatischer Calamoceratidae (Trichoptera) (Arbeit über thailändische Köcherfliegen Nr. 13). Zeitschrift der Arbeitsgemeinschaft Österreichischer Entomologen, 46, 62-79.

Malicky, H. (1995) Neue Köcherfliegen (Trichoptera, Insecta) aus Vietnam. Linzer Biologische Beiträge, 27, 851-885.

Malicky, H. (2007) A survey of the Trichoptera of Sumatra. In: Bueno-Soria, J., Barba-Álvarez, R. \& Armitage, B.J. (Eds.), Proceedings of the 12th International Symposium on Trichoptera. The Caddis Press, Columbus, Ohio, pp. 175-179.

Malicky, H. (2010) Atlas of Southeast Asian Trichoptera. Biology Department, Faculty of Science, Chiang Mai University, Chiang Mai.

Malicky, H. (2013) Synonyms and possible synonyms of asiatic Trichoptera / Synonyme und mögliche Synonyme von asiatischen Köcherfliegen. Braueria, 40, 41-54.

Malicky, H. \& Chantaramongkol, P. (2007) Beiträge zur Kenntnis asiatischer Hydroptilidae (Trichoptera). Linzer Biologische Beiträge, 39, 1009-1099.

Malicky, H., Chantaramongkol, P., Cheunbarn, S. \& Saengpradab, N. (2001) Einige neue Köcherfliegen (Trichoptera) aus Thailand (Arbeit Nr. 32 über thailändische Köcherfliegen). Braueria, 28, 11-14.

Malicky, H., Melnitsky, S. \& Ivanov, V.D. (2014) Köcherfliegen von Kambodscha, mit der Beschreibung einer neuen OecetisArt (Trichoptera). Braueria, 41, 33-34.

McLachlan, R. (1863) On Anisocentropus, a new genus of exotic Trichoptera, with descriptions of five species, and of a new species of Dipseudopsis. Transactions of the Entomological Society of London, 3rd Series 1, 492-496, plate 19. https://doi.org/10.1111/j.1365-2311.1863.tb01297.x

Mey, W. (1997) Die Köcherfliegenfauna des Fan Si Pan-Massivs in Nord-Vietnam. 2. Beschreibung neuer und endemischer Arten aus der Unterordnung Integripalpia (Insecta: Trichoptera). Entomofauna, 18, 197-212.

Mey, W. (1998) Die Köcherfliegenfauna des Fan Si Pan-Massivs in Nord-Vietnam. 3. Beschreibung weiterer neuer Arten (Trichoptera). Opuscula Zoologica Fluminensia, 165, 1-17.

Morse, J.C. (2016) Keynote: The Trichoptera fauna of Asia. In: Vshivkova, T.S. \& Morse, J.C. (Eds.), Proceedings of the $14^{\text {th }}$ International Symposium on Trichoptera. Zoosymposia, 10, 20-28. https://doi.org/10.11646/zoosymposia.10.1.4

Morse, J.C. (Ed.) (2019) Trichoptera World Checklist. Available from: http://entweb.clemson.edu/database/trichopt/index.htm (accessed 20 December 2019)

Mosely, M.E. (1939) Trichoptera. Ruwenzori Expedition 1934-35. British Museum (Natural History), 3, 1-40.

Nuntakwang, A., Chantaramongkol, P. \& Courtney, G.W. (2007) Biodiversity and biogeographic connections of Trichoptera 
from mountain streams of northern Thailand. In: Bueno-Soria, J., Barba-Álvarez, R. \& Armitage, B.J. (Eds.), Proceedings of the 12th International Symposium on Trichoptera. The Caddis Press, Columbus, Ohio, pp. 257-262.

Oláh, J. (1989) Thirty-five new hydroptilid species from Vietnam (Trichoptera, Hydroptilidae). Acta Zoologica Hungarica, 35 , 255-293.

Oláh, J. \& Johanson, K. (2010) Description of 33 new species of Calamoceratidae, Molannidae, Odontoceridae and Philorheithridae (Trichoptera), with detailed presentation of their cephalic setal warts and grooves. Zootaxa, 2457, 1-128. https://doi.org/10.11646/zootaxa.2457.1.1

Oláh, J. \& Johanson, K. (2010) Description of 46 new Old World Hydroptilidae (Trichoptera). Folia Entomologica Hungarica, $71,1-91$.

Prommi, T-o. \& Chantaramongkol, P. (2005) A preliminary survey of adult Trichoptera communities in Thongphaphum district, Kanchanaburi Province, Thailand. In: Tanida, K. \& Rossiter, A. (Eds.), Proceedings of the 11th International Symposium on Trichoptera. Kanagawa, Tokai University Press, Kanagawa, pp. 355-361.

Schmid, F. (1958) Trichoptères de Ceylan. Archiv für Hydrobiologie, 54, 1-173.

Seetapan, K. \& Prommi, T-o. (2012) Light-trapping of caddisflies (Insecta: Trichoptera) as Champathong Waterfall, northern Thailand with reference to local climate. Entomological Research Bulletin, 28, 59-63.

Stephens, J. (1836-1837) Illustrations of British Entomology; or a Synopsis of Indigenous Insects: Containing their Generic and Specific Distinctions; with an Account of their Metamorphoses, Times of Appearance, Localities, Food, and Economy, as far as Practicable. Mandibulata. Vol. VI. Baldwin and Cradock, London.

Ulmer, G. (1905) Neue und wenig bekannte aussereuropäische Trichopteren, hauptsächlich aus dem Wiener Museum. Annalen des Kaiserlich-Königlichen Naturhistorischen Hofmuseums Wien, 20, 59-98.

Ulmer, G. (1906) Neuer beitrag zur kenntnis aussereuropäischer Trichopteren. Notes from the Leyden Museum, $28,1-116$.

Ulmer, G. (1915) Trichopteren des Ostens, besonders von Ceylon und Neu-Guinea. Deutsche Entomologische Zeitschrift, 1, 41-75. https://doi.org/10.1002/mmnd.48019150108

Ulmer, G. (1926) Beiträge zur Fauna sinica III. Trichopteren und Ephemeropteren. Archiv für Naturgeschichte, Abteilung A, 91 , 19-110.

Ulmer, G. (1951) Köcherfliegen (Trichopteren) von den Sunda-Inseln. Teil I. Archiv für Hydrobiologie, Supplement, 19, 1-528, plates 1-28.

Wells, A. \& Huisman, J. (1993) Malaysian and Bruneian micro-caddisflies in the tribes Stactobiini and Orthotrichiini (Trichoptera: Hydroptilidae: Hydroptilinae). Zoologische Mededelingen (Leiden), 67, 91-125.

Xue, Y. \& Yang, L-f. (1990) Seven new species of Hydroptilidae from China (Insecta: Trichoptera). Acta Agricultura Universitatis Henanensis, 24, 124-131.

Yang, L-f., Sun, C.-h., Wang, B.-x. \& Morse, J.C. (2005) Present status of Chinese Trichoptera, with an annotated checklist. In: Tanida, K. \& Rossiter, A. (Eds.), Proceedings of the 11th International Symposium on Trichoptera. Tokai University Press, Kanagawa, pp. 441-460.

Yang, L-f., Sun, C.-h. \& Morse, J.C. (2016) An amended checklist of the caddisflies of China (Insecta, Trichoptera). Zoosymposia, 10, 451-479. https://doi.org/10.11646/zoosymposia.10.1.42

Zhou, X., Frandsen, P.B., Holzenthal, R.W., Beet, C.R., Bennett, K.R., Blahnik, R.J., Bonada, N., Cartwright, D., Chuluunbat, S., Cocks, G.V., Collins, G.E., deWaard, J., Dean, J., Flint, O.S., Hausmann, A., Hendrich, L., Hess, M., Hogg, I.D., Kondratieff, B.C., Malicky, H., Milton, M.A., Morinière, J., Morse, J.C., Mwangi, F.N., Pauls, S.U., Gonzalez, M.R., Rinne, A., Robinson, J.L., Salokannel, J., Shackleton, M., Smith, B., Stamatakis, A., StClair, R., Thomas, J.A., Zamora-Muñoz, C., Ziesmann, T. \& Kjer, K.M. (2016) The Trichoptera barcode initiative: A strategy for generating a species-level Tree of Life. Philosophical Transactions of the Royal Society B, 371, 1-11. https://doi.org/10.1098/rstb.2016.0025 